Vol. 54, z. $1-2001$

s. $31-43$

\title{
Differential antifungal activity of alfalfa (Medicago sativa L.) saponins originated from roots and aerial parts for some ornamental plant pathogens
}

\section{ALICJA SANIEWSKA*, MARIAN JURZYSTA**, ZBIGNIEW BIALY**}

\footnotetext{
*Research Institute of Pomology and Floriculture, Pomologiczna 18, 96-100 Skierniewice, Poland

** Department of Biochemistry and Plant Quality, Institute of Soil Science and Plant Cultivation, Czartoryskich 8, 24-100 Puławy, Poland
}

(Received: 20.04.2001)

\section{Sum mary}

The total saponins isolated from aerial parts and roots of alfalfa (Medicago sativa L.) at the concentration of $0.01 \%, 0.05 \%$ and $0.1 \%$ showed differential influence on the mycelium growth of Alternaria zinniae, Botrytis cinerea, Botrytis tulipae, Phoma narcissi, Phoma poolensis and Rhizoctonia solani. A higher inhibitory effect on in vitro growth of mycelium of all tested pathogens indicated saponins from roots of alfalfa than from aerial parts.

Tested saponins from roots at the concentration of $0.1 \%$ totally inhibited linear growth of Phoma narcissi, and linear growth of Alternaria zinniae was limited about $67 \%$, Botrytis cinerea about $74 \%$, Botrytis tulipae about $68 \%$, Phoma poolensis about $38 \%$, and Rhizoctonia solani about $74 \%$ in comparison to the control.

The saponins of alfalfa from roots at the concentration of $0.1 \%$ and $0.2 \%$ applied as preinoculation sprays evidently inhibited the development of Phoma narcissi on Hippeastrum leaves. This dose of aerial saponins of alfalfa did not effect the development of necrotic spots on the leaves.

Key words: Medicago sativa, alfalfa saponins, fungal pathogens, mycelium growth, protective role 


\section{INTRODUCTION}

Saponins (glycosylated triterpenoid or steroid molecules) are widely distributed in higher plants. Saponins occurring in alfalfa (Medicago sativa L.) are composed of a complicated mixture of triterpenoid glycosides (P r i c e et al., 1987; O l e s z e k et al., 1992a; O le s z e k, 1996; B i a ły et al., 1999).

According to the structure of aglycones, they can be divided into several groups: derivatives of medicagenic acid, oleanolic acid, zanhic acid, hederagenin, and soyasapogenols.

Many saponins have been shown to have potent antifungal activities and often occur in healthy plants at levels which are anticipated to be toxic to saponinsensitive fungi. The fungistatic activity of saponins could be demonstrated both in vivo and in vitro.

Alfalfa saponins possess selective toxicity against Trichoderma viride ( $\mathrm{J} \mathrm{u} \mathrm{r} z$ y s t a and W a 11 e r, 1996; O le s z e k et al., 1990), several plant pathogenic fungi ( $\mathrm{Z}$ e h a v i and P o l a c h e c k, 1996; M a r t y n i k et al., 1996, 1999; Zentmeyer and Thompson, 1967; Le atch et al., 1972; Pedersen et al., 1976; Levy et al., 1986), and medically important fungi ( $\mathrm{Z} \mathrm{a} \mathrm{h} \mathrm{a} \mathrm{v} \mathrm{i} \mathrm{and}$ P o l a c h e c k, 1996; P o l a c h e c k et al., 1986; Ś p i e w a k et al., 2000a,b).

Until now the response of the following plant pathogenic fungi to alfalfa saponins were tested in vitro: Phytophthora cinnamomi $(\mathrm{Z}$ e $\mathrm{n} \mathrm{t} \mathrm{m}$ e y e $\mathrm{r}$ and T h o m p s o n, 1967), Ascochyta imperfecta, Colletotrichum destructivum, Fusarium oxysporum f. medicaginis, Leptosphaerulina briosiana, Pythium irregulare, Pythium ultimum, Sclerotinia trifoliorum, Stemphylium botryosum, Phytophthora megasperma (L e a $\mathrm{th}$ et al., 1972), Aspergillus niger, Fusarium oxysporum f. sp. lycopersici, Pythium aphanidermatum, Rhizoctonia solani, Sclerotium rolfsii, Rhizopus mucco ( $\mathrm{Ze} \mathrm{h} \mathrm{a} \vee \mathrm{i}$ and $\mathrm{P} \circ \mathrm{l}$ a $\mathrm{ch}$ e $\mathrm{ck}$, 1996), Cephalosporium gramineum, Gaeumannomyces graminis v. tritici (M a r t y n i u k et al., 1996, 1999).

The aim of the present work is determination in vitro of the fungitoxic activity of saponins originated from root and aerial parts of alfalfa to a few species of pathogenic fungi, which were not tested for saponins response.

\section{MATERIAL AND METHODS}

\section{Chemicals}

Total saponins have been isolated from aerial parts and roots of alfalfa (Medicago sativa L.) 'Radius', according to the known methods ( $\mathrm{O} \mathrm{l}$ e s z e $\mathrm{k}$ et al., 1992b; B i a ł y et al., 1999) as follow: defatted plant material was extracted with boiling methanol. After removing of alcohol, the residue was dissolved in water. The solution was placed on LiChroprep RP-18 (25-40 mm) column preconditioned with water. The column was washed with water and $30 \%$ methanol successively. Total saponins were eluated with methanol and dried at $60^{\circ} \mathrm{C}$. 
In vitro growth of some pathogenic fungi in the presence of saponins from Medicago sativa. Alternaria zinniae Pope, Botrytis cinerea Pers. [= Botryotinia fuckieliana (de Bary) Whetzel], Botrytis tulipae (Lib.) Lind, Phoma narcissi Aderh. [syn. Stagonospora curtisii (Berk.) Sacc.], Phoma poolensis Taub. (syn. Phyllosticta antirrhini Syd.) i Rhizoctonia solani Kühn. [= Tanatephorus cucumeris (Frank) Donk.] were used in all trials. Saponins of Medicago sativa from aerial (foliage) parts and from roots at final concentration $0.01 \%$; $0.05 \%$ and $0.1 \%$ were dissolved in $5 \mathrm{~cm}^{3}$ distilled and sterilized water and added to potato-dextrose-agar (PDA - Difco) after sterilization at temperature of about $50^{\circ} \mathrm{C}$. Five $\mathrm{mm}$ diam. plugs taken from 7-day-old culture of tested fungi, were placed in the middle of $90 \mathrm{~mm}$ Petri dishes containing PDA medium supplemented with tested compounds. Control plates constituted the culture growing on PDA without any amendments.

The diameter of the fungi colony was measured within an 8 day-incubation at $25^{\circ} \mathrm{C}$ in darkness. Five dishes were used for each treatment and the experiment was repeated 2 times.

Influence of saponins in the control of Phoma narcissi on Hippeastrum hybr. hort.

Development of red spot on intact leaves of Hippeastrum 'Jan' in presence of saponins from root and aerial parts at a concentration $0.1 \%$ and $0.2 \%$ was evaluated. The compounds were applied on leaves preventively. Intact leaves were sprayed with saponins $1 \mathrm{~h}$ before inoculation with Phoma narcissi. Tween 80 was added to the solution to improve wettability. Five mm diam. plugs of mycelium taken from 5-dayold culture of Phoma narcissi grown on PDA were put on the surface of leaves in three places on each one. Control leaves were sprayed with distilled water containing Tween 80 but no saponins, and inoculated with disks of mycelium of $P$. narcissi.

All plants with inoculated leaves were kept in a small plastic tunnel on greenhouse bench with high humidity inside. Five pots plants of Hippeastrum with four leaves each were used for each treatments and experiment were repeated three times.

The data were subjected to an analysis of variance and Duncan's multiple range test at $5 \%$ of significance was used for means separation.

\section{RESULTS AND DISCUSSION}

Total saponins isolated from aerial and roots of alfalfa (Medicago sativa L.) at the concentration of $0.01 \%, 0.05 \%$, and $0.1 \%$ showed differential influence on the mycelium growth of Alternaria zinniae, Botrytis cinerea, Botrytis tulipae, Phoma narcissi, Phoma poolensis and Rhizoctonia solani (Fig. 1 and 2). All tested pathogens indicated saponins from roots of alfalfa had a higher inhibitory effect on in vitro growth of mycelium than those from aerial parts (Fig. 1 and 2). The saponins from roots, used at the lowest concentrations, evidently inhibited in vitro growth, with a marked effect at higher concentrations (Fig. 1). After 6 days of incubation at the concentration $0.1 \%$, linear growth of Phoma narcissi was totally inhibited, and linear growth of Alternaria zinniae was limited about $67 \%$, Botrytis cinerea about $74 \%$, Botrytis tulipae about $68 \%$, Phoma poolensis about $38 \%$, Rhizoctonia solani about $73 \%$ in comparison to the control (Fig. 1 and 2). 
The total saponins from aerial parts of alfalfa showed a less inhibitory effect on the growth of tested pathogens (Fig. 1 and 2). These saponins had a strong inhibitory effect for mycelium growth of Phoma narcissi and Botrytis tulipae. Applied at a concentration of $0.1 \%$ inhibited the growth of the pathogens in $64 \%$ and $48 \%$, respectively. The linear growth of Alternaria zinniae was limited about $33 \%$, Botrytis cinerea about $14 \%$, and Phoma poolensis about $17 \%$. This dose of aerial saponins did not effect the mycelium growth of Rhizoctonia solani. It is well known that the high fungitoxic activity of alfalfa saponins is due to glycosides of medicagenic acid and hederagenin, which occur in higher concentrations in alfalfa roots than in shoots (O l e s z e k et al., 1992b).

Medicagenic acid 3-(O-glucopyranoside) isolated from alfalfa roots demonstrates high activity against Trichodema viride as well as against some important plant pathogens: Sclerotium rolfsii, Rhizopus mucco, Aspergillus niger, Phytophthora cinnamomi, Fusarium oxysporum f. sp. lycopersici ( $\mathrm{L}$ e v y et al., 1986). The same compound was toxic to ten medically important yeasts (Candida sp., Torulopsis sp., Geotrichum candidum) (P o l a c h e c k et al., 1986).

Generally a positive relationship has been found between fungistatic and haemolytic activities of root tissue saponin extract of Medicago ( $\mathrm{J} \mathrm{u} \mathrm{r} \mathrm{z} \mathrm{y} \mathrm{s} \mathrm{t} \mathrm{a} \mathrm{and}$ B i a $ł$ y, 1999).

F o c k e (1970) reported that fungi pathogenic to alfalfa showed a greater tolerance for saponins than did fungi not pathogenic to alfalfa and postulated that saponins may have a function in a non-specific type of disease resistance.

Saponins obtained from roots and aerial parts of alfalfa had the most inhibitory effect to Phoma narcissi among other tested pathogens in our study.

In studies by $\mathrm{S} \mathrm{z} \mathrm{c} \mathrm{z} \mathrm{e} \mathrm{p} \mathrm{a} \mathrm{n} \mathrm{i} \mathrm{k}$ et al. (2001) no significant differences in activity against Colorado potato beetle larvae (Leptinotarsa decemlineata) have been found between root and shoot saponins of alfalfa. Similar results have been obtained by $\mathrm{T}$ a $\mathrm{v}$ a and O d o a r d i (1996) in their studies on the insecticidal activity of saponins from the roots and the leaves of alfalfa towards the European grape moth (Lobesia botrana). On the other hand, the results of studies carried out by N o z z o lill lo et al. (1997) and A d e l et al. (2000) point to a higher activity of root saponins compared with shoot ones.

The principle of the fungitoxic activity of saponins is an interaction with fungal membrane sterols, and probably with proteins and phospholipids ( $\mathrm{G} \mathrm{r} \mathrm{u} \mathrm{i} \mathrm{z} \mathrm{and}$ B i a c s, 1989; B i a c s and G r u i z, 1984; G r u i z, 1996; A s s a et al., 1972, 1975). The attact of saponins on various membrane constituents caused changes in membrane permeability and lysis. Differential fungitoxic of alfalfa saponins to different species of pathogenic fungi is possibly dependent on membrane compositions of pathogens.

Total saponins, isolated from roots of alfalfa applied at a concentration of $0.1 \%$ and $0.2 \%$ as preinoculation sprays, had 4 days later inhibited the development of necrotic spots on Hippeastrum leaves (tab. 1). After an 8-day-incubation, the length of necrotic spots was at least $43 \%$ smaller than of controls. This dose of aerial saponins of alfalfa did not effect the development of Phoma narcissi on Hippeastrum leaves, and at higher concentrations $(0.2 \%)$ aerial saponins gave a stimulatory effect to the development of Phoma narcissi on the leaves. 
Table 1

The effect of total saponins isolated from aerial parts and roots of alfalfa (Medicago sativa L.) on the development of Phoma narcissi on Hippeastrum leaves: spraying $1 \mathrm{~h}$ before inoculation

\begin{tabular}{|c|c|c|}
\hline \multirow{2}{*}{$\begin{array}{c}\text { Saponins source and conc. } \\
\text { in \% }\end{array}$} & \multicolumn{2}{|c|}{ Length of necrotic spots (mm) after days of incubation } \\
\cline { 2 - 3 } & 4 & 8 \\
\hline Control untreated & $9.4 \mathrm{~b}$ & $17.4 \mathrm{~b}$ \\
Root 0.1 & $4.1 \mathrm{a}$ & $10.2 \mathrm{a}$ \\
Root 0.2 & $4.7 \mathrm{a}$ & $11.0 \mathrm{a}$ \\
Aerial 0.1 & $8.9 \mathrm{~b}$ & $16.8 \mathrm{~b}$ \\
Aerial 0.2 & $12.6 \mathrm{c}$ & $24.6 \mathrm{c}$ \\
\hline
\end{tabular}

Explanation: Means in columns followed by the same letters are not significantly different at $5 \%$ level.

Thus, the root saponins of alfalfa, in a much smaller degree, inhibited the development of disease induced by Phoma narcissi on Hippeastrum than the mycelium growth of the pathogen in vitro. It is possible that glycosides of medicagenic acid and hederagenin are degradated to free aglycones by glycosyl hydrolases of Hippeastrum tissues which remove sugar molecules from glycosyl chain. Fungitoxic activities of aglycones are weaker to fungal growth than glycosides of the compounds. This kind of detoxification of saponin is known by some plant pathogenic fungi ( $\mathrm{O}$ s b u r $\mathrm{n}$ et al., 1996). It is well known also that fungitoxic activity of saponins can be strongly modified by the structure of sugar chain (O s b u r n et al.,1996; B i a ł y and J u r z y s t a, 2000).

\section{REFERENCES}

A d e 1 M.M., S e h n a 1 F., J u r z y s t a M., 2000. Effects of alfalfa saponins on the moth Spodoptera littoralis. J. Chem. Ecol. 26: 1065-1078.

A s s a Y., Geste tne r B., Che t J., Hen is Y., 1972. Fungistatic activity of luceme saponins and digitonin as related to sterols. Life Science 11: 637-647.

A s s a Y., Chet J., Gestetner B., Govrin R., B irk Y., B ond i A., 1975. The effect of alfalfa saponins on growth and lysis of Physarum polycephalum. Arch. Microbiol.103: 77-80.

B i a c s P.A., G r u i z K., 1984. Membrane-lipid composition and saponin sensitivity of different mould strains. In: Structure, Function and Metabolism of Plant Lipids, P.A. Siegenthaler and W. Eichenberger (eds.), Elsevier, Amsterdam, pp. 353-356.

B i a $ł$ y A., J u r z y s t a M., 2000. Wpływ saponin korzeni lucemy siewnej (Medicago sativa L.) na wzrost grzyba Trichoderma viride. Progress in Plant Protection/Posteppy w Ochronie Roślin 40 (2): 706-708.

B i a 1 y Z., J urz y s t a M., O le szek W.,Pia cente S., Pizza C., 1999. Saponins in alfalfa (Medicago sativa L.) root and their structural elucidation. J. Agric. Food. Chem. 47: 3185-3192.

F o c k e I., 1970. Luzernesaponine and Epiphytenflora. Arch. Pflanzenschutz 6: 119-124.

G r u i z K., B i a c s P.A., 1989. Membrane lipid composition of Trichoderma strains and their sensitivity to saponin and polyene antibiotics. In: Biological Role of Plant Lipids, P.A. Biacs, K. Gruiz, and T. Kremmer (eds.), Akadémiai Kiadó, Budapest and Plenum, New York and London, pp. 417-420. 
G r u i z K., 1996. Fungitoxic activity of saponins: Practical use and fundamental principles. In: Saponins Used in Traditional and Modern Medicine, G.R. Waller and K. Yamasaki (eds.), Plenum Press, New York, pp. 527-534.

J urz y s t a M., B i ał y Z., 1999. Antifungal and haemolytic activity of roots of alfalfa (Medicago spp.) in relation to saponin composition. In: Modern Fungicides and Antifungal Compounds, H. Lyr, E. Pussoll, H.D. Lisler, Intercep, Andover, UK, pp. 445-451.

J u r z y s t a M., W a 11 e r G.R., 1996. Antifungal and haemolytic activity of aerial parts of alfalfa (Medicago) species in relation to saponin composition. In: Saponins Used in Traditional and Modern Medicine, G.L. Waller and K. Yamasaki (eds.), Plenum Press, New York, pp. 565-574.

L e a th K.T., D a v i s K.H., Jr., W a 11 M.E., H a n s o n C.H., 1972. Vegetative growth responses of alfalfa pathogens to saponin and other extracts from alfalfa (Medicago sativa L.). Crop Science 12: 851-855.

Le v y M., Z e h a vi U., N a i m M., P o l a c he ck I., 1986. An improved procedure for the isolation of medicagenic acid 3-O-D-glucopyranoside from alfalfa roots and its antifungal activity on plant pathogen. J. Agric. Food. Chem. 34: 960-963.

M art y ni u k S., W róblew s k a B., Jurzy st a M., B i a ł y Z., 1996. Saponins as inhibitors of cereal pathogens: Gaeumannomyces graminis v. tritici and Cephalosporium gramineum. In: Modern Fungicides and Antifungal Compounds, H. Lyr, P.E. Pussell, H.D. Sisler (eds.), Intercept, Andover, UK, pp. 193-197.

M ar t y n i uk S., J urz y s t a M., W r ó ble w s k a B., 1999. Influence of powdered aerial parts of various Medicago species on the growth of Gaeumannomyces graminis and Cephalosporium gramineum. Bull. Pol. Acad. Sci., Biol. Sci. 47: 163-165.

Nozzolillo C., Arna s on J.T., C a m p os F., Donskov N., Jurzy sta M., 1997. Alfalfa leaf saponins and insect resistance. J. Chem. Ecol. 23: 995-1002.

O l e s z e k W., J u r z y s t a M., G ó r s k i P.M., 1992a. Alfalfa saponins - the allelopathic agents. In: Allelopathy: Basic and Applied Aspects, S.J.H. Rizvi and V. Rizvi (eds.), Chapman and Hall, London, pp. 151-164.

O leszek W., Jurzysta M., Plosz ynski M., C ol o qu houn I.J.,Price K.R., F e n w i c k G.R., 1992b. Zanhic acid tridesmoside and other dominant saponins from alfalfa (Medicago sativa L.) aerial parts. J. Agric. Food Chem. 40: 191-196.

O le s z e k W., 1996. Alfalfa saponins: Structure, biological activity and chemotaxonomy. In: Saponins Used in Food and Agriculture, G.R. Waller and K. Yamasaki (eds.), Plenum Press., New York, pp. 155-170.

Oleszek W.,Pric e K.R., C ol o quh oun I.J., Jurzys ta M., Ploszynski M., F e n w i c k G.R., 1990. Isolation and identification of alfalfa (Medicago sativa L.) root saponins: their activity in relation to a fungal bioassy. J. Agric. Food Chem. 38: 1810-1817.

O s bur n A., B o w y e r P., D a n i e 1 s M.J., 1996. Saponin detoxification by plant pathogenic fungi. In: Saponins Used in Traditional and Modern Medicine, G.R. Waller and K. Yamasaki (eds.), Plenum Press, New York, pp. 547-555.

P e der se n M.W., B arne s D.K., S or en se n E.L., G r iff in D., N i e 1 s on M.W., Hill R.R., Jr., Fro s he is e r F.I., S o n o d a R.M., H a n s on C.H., H u n t O.J., $P$ e a d e $n$ R.A., E $1 \mathrm{~g}$ i n J.H., Jr., D e v i n e T.E., A n d e r s o n M.J., Gop 1 e n B.P., E $11 \mathrm{ing}$ L.J., H o w a r t h R.E., 1976. Effects of low and high saponin selection in alfalfa on agronomic and pest resistance traits and the interrelationship of these traits. Crop Science 16: 193-199.

P o l a c he ck I., Z e h a v i U., N a i m M., L e v y M., Ev r on R., 1986. Activity of compound G2 isolated from alfalfa roots against medically important yeasts. Antimicrob. Agents Chemother. 30: 290-294.

P r i c e K.R., J o h n s o n I.T., F e n w i c k G.R., 1987. The chemistry and biological significance of saponins in foods and feedingstuffs. CRC Crit. Rev. Food Sci. Nutr. 26: $27-135$. 
Śpie wa k. R., S z os t a k W., Ju r z y s t a M., B i a ł y Z., 2000a. Inhibitory action of medicagon acid 3-glucoside on the growth of Scopulariopsis brevicaulis in vitro. Mikrobiologia Lekarska, Suplement 1, tom 7, Poster 16.

S p i e wa k R., S z o s t a k W., Jurz y s t a M., B i a 1 y Z., 2000b. Inhibitory action of medicagon acid 3-glucoside on the growth of Trichophyton mentagrophytes in vitro. Mikrobiologia Lekarska, Suplement 1, tom 7, Poster 17.

S z c ze panik M., Krystk ow iak K., Jurzy st a M., B i ały Z., 2001. Biological activity of alfalfa saponins in the Colorado potato beetle larvae. J. Plant Protec. Res. (in press).

T a v a A., O d o a r di M., 1996. Saponins from Medicago spp.: Chemical characterization and biological activity against insects. In: Saponins Used in Food and Agriculture, G.R. Waller and K. Yamasaki (eds.), Plenum Press,. New York, pp. 97-109.

Z e h a v i U., P o l a c h e c k I., 1996. Saponins as antimycotic agents: glycosides of medicagenic acid. In: Saponins Used in Traditional and Modem Medicine, G.R. Waller and K. Yamasaki (eds.), Plenum Press, New York, pp. 535-546.

Z e n t m e y e r G.A., T h o m p s o n C.R., 1967. The effect of saponins from alfalfa on Phytophthora cinnamomi in relation to control of root rot of avocado. Phytopathology 57:1278-1279.

\section{Zróżnicowana aktywność antygrzybowa saponin z korzeni i części nadziemnych lucerny siewnej (Medicago sativa L.) dla kilku patogenów roślin ozdobnych}

\section{Streszczenie}

Badano fungitoksyczny wpływ sumy saponin, pozyskanych z cześci nadziemnych i korzeni lucemy siewnej (Medicago sativa L.), w stosunku do kilku gatunków grzybów chorobotwórczych dla roślin ozdobnych. Badane sumy saponin w stężeniu $0,01 \% ; 0,05 \%$ i $0,1 \%$ wykazały zróżnicowany wpływ na wzrost Alternaria zinniae, Botrytis cinerea, Botrytis tulipae, Phoma narcissi, Phoma poolensis i Rhizoctonia solani $w$ warunkach in vitro na pożywce ziemniaczano-glukozowej (PDA). Suma saponin pozyskana $z$ korzeni, w najwyższym zastosowanym stẹżeniu $(0,1 \%)$, całkowicie zahamowała wzrost grzybni Phoma narcissi, a wzrost grzybni pozostałych badanych gatunków był silnie ograniczony; Alternaria zinniae o 67\%, Botrytis cinerea o $74 \%$, Botrytis tulipae o $68 \%$, Phoma poolensis o $38 \%$ i Rhizoctonia solani o $74 \%$ w porównaniu do kultur kontrolnych wzrastających na pożywce bez dodatku saponin. Suma saponin pozyskana z czẹści nadziemnych wykazała słabszy fungitoksyczny wpływ na wzrost liniowy testowanych gatunków grzybów. Ta grupa saponin najsilniej hamowała wzrost Phoma narcissi i Botrytis cinerea. Wzrost liniowy grzybni tych gatunków był ograniczony, odpowiednio, o $64 \%$ i $48 \%$ w stosunku do kultury kontrolnej. Wzrost grzybni Alternaria zinniae był zahamowany o 33\%, Botrytis cinerea o $14 \%$ i Phoma poolensis o $17 \%$. Saponiny z czẹści nadziemnych, w zastosowanych stẹżeniach, nie wpłynẹły hamująco na wzrost grzybni Rhizoctonia solani. W warunkach in vivo suma saponin pozyskana $\mathrm{z}$ korzeni lucerny siewnej, zastosowana profilaktycznie do opryskiwania liści Hippeastrum w stẹżeniu $0,1 \%$ i $0,2 \%$ wpłynẹła hamująco na rozwój Phoma narcissi. Zastosowane w tych samych stężeniach saponiny pozyskane z czẹści nadziemnych nie wpłynẹły ograniczająco na rozwój nekrotycznej plamistości na liściach Hippeastrum. 
Fig. 1. Inhibitory effect of total saponins isolated from aerial parts and roots of alfalfa

(Medicago sativa) on in vitro mycelium growth of Alternaria zinniae, Botrytis cinerea, Botrytis tulipae, Phoma narcissi, Phoma poolensis and Rhizoctonia solani.

Explanation: Means followed by the same letters are not significantly different at $5 \%$ level.

\section{Botrytis cinerea}

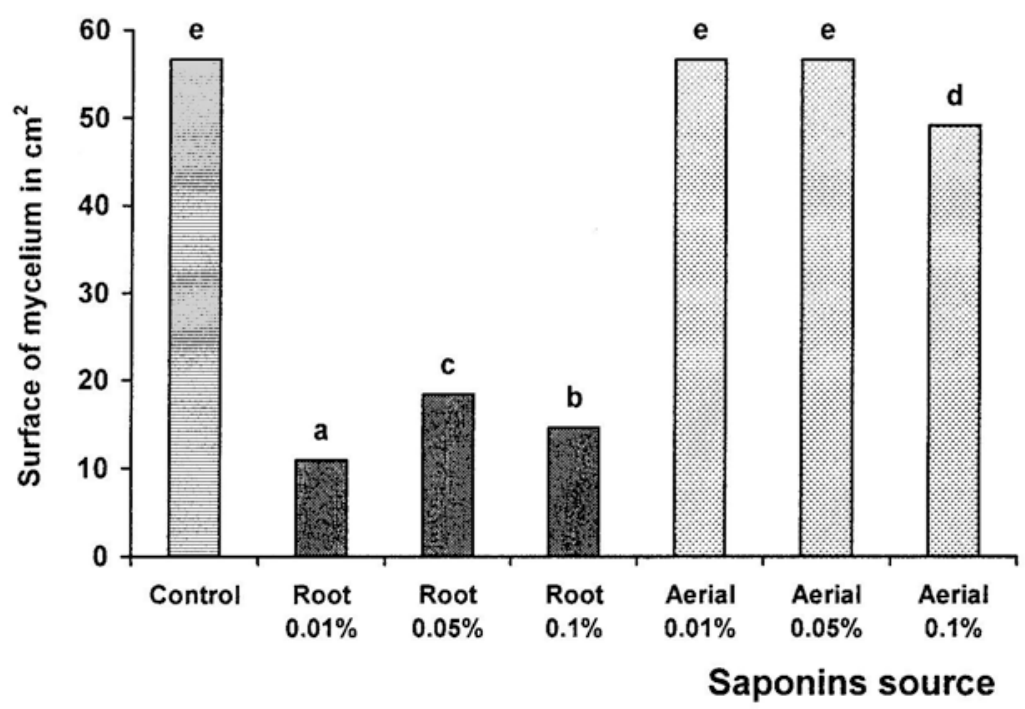

Botrytis tulipae

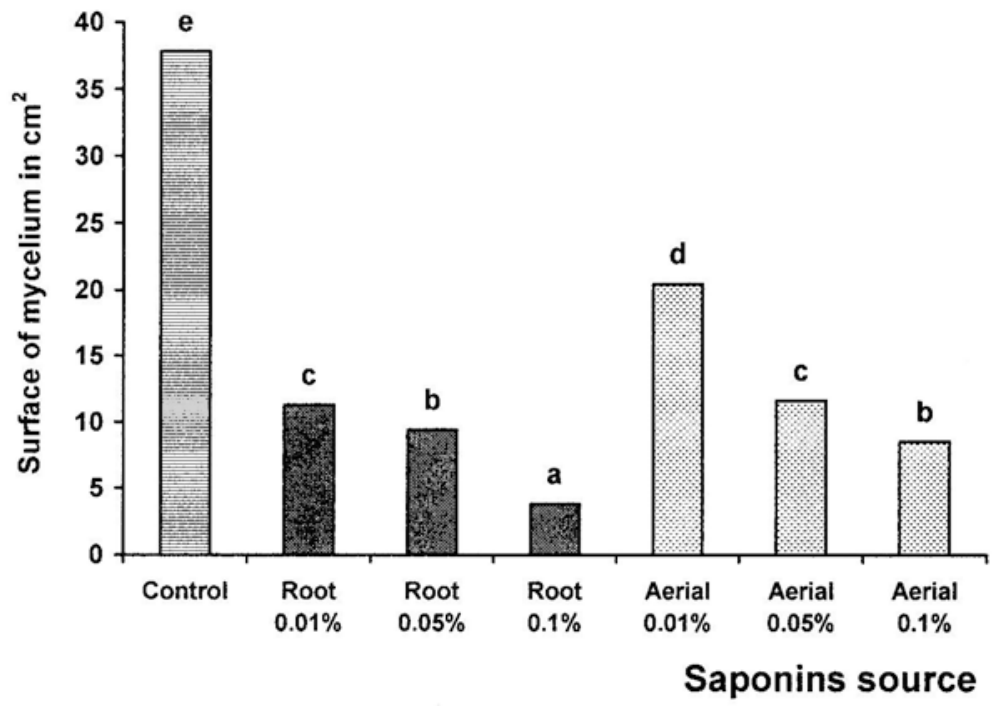




\section{Phoma narcissi}

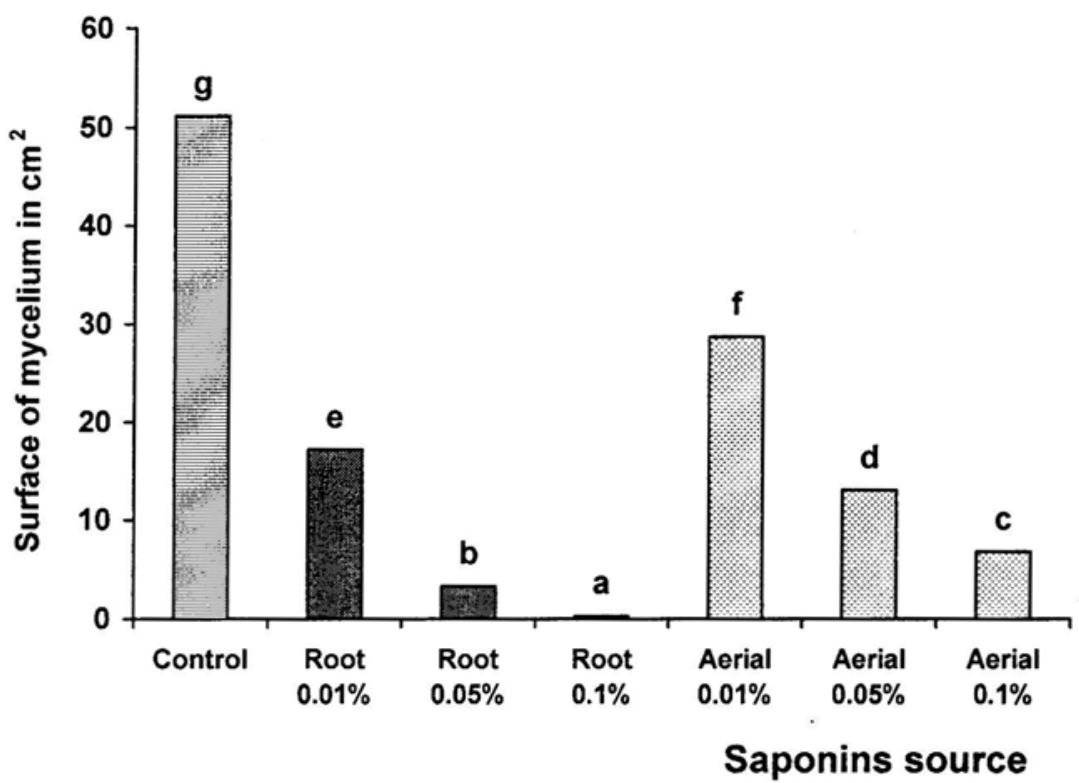

\section{Phoma poolensis}

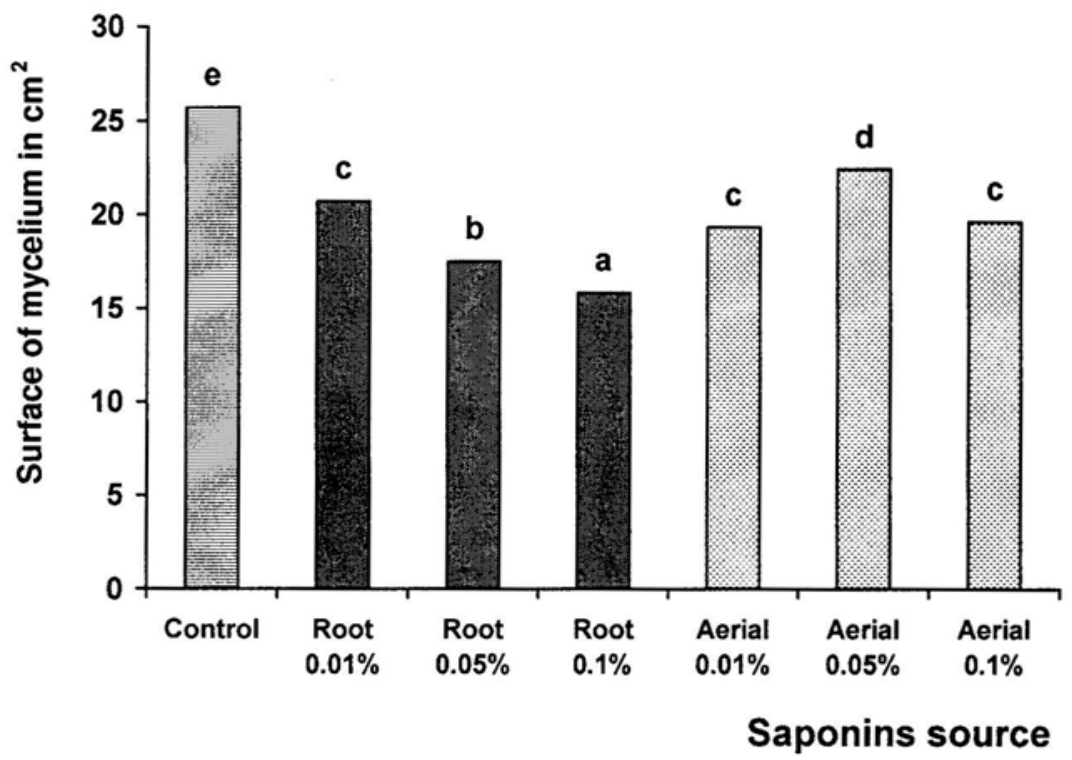




\section{Alternaria zinniae}

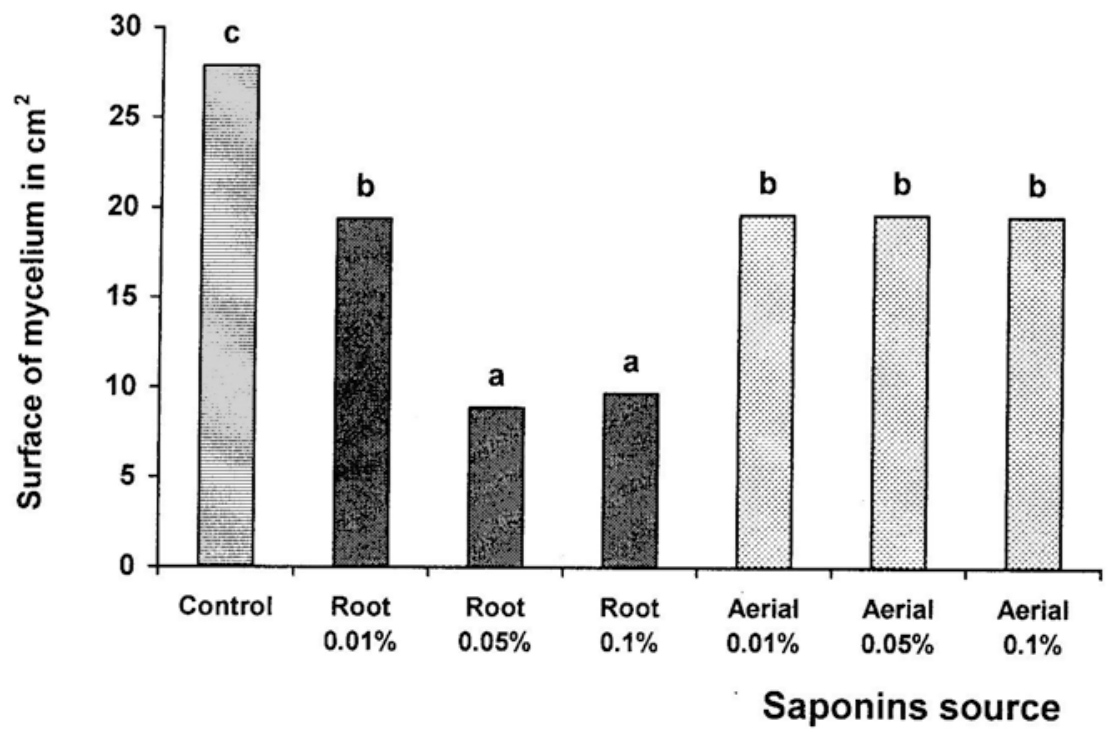

Rhizoctonia solani

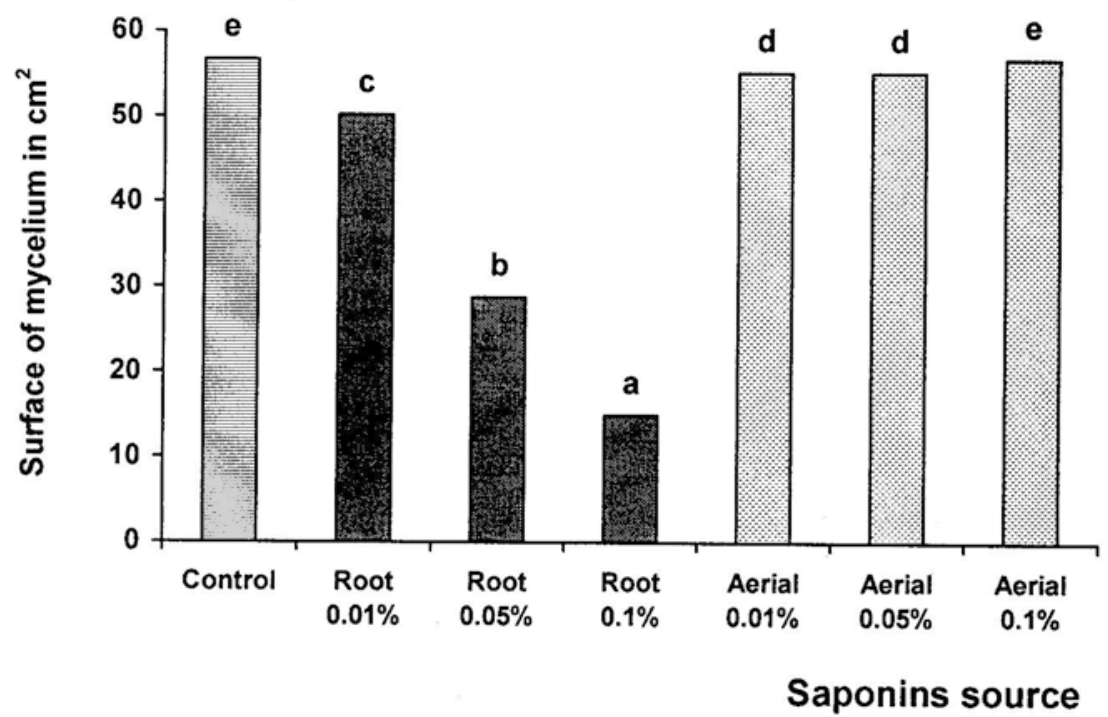


Fig. 2. Mycelium growth of Alternaria zinniae, Botrytis cinerea, Botrytis tulipae, Phoma narcissi, Phoma poolensis and Rhizoctonia solani on potato-dextrose-agar supplemented with total saponins from roots of alfalfa (Medicago sativa) on left - control; on right - saponin at conc. of $0.1 \%$
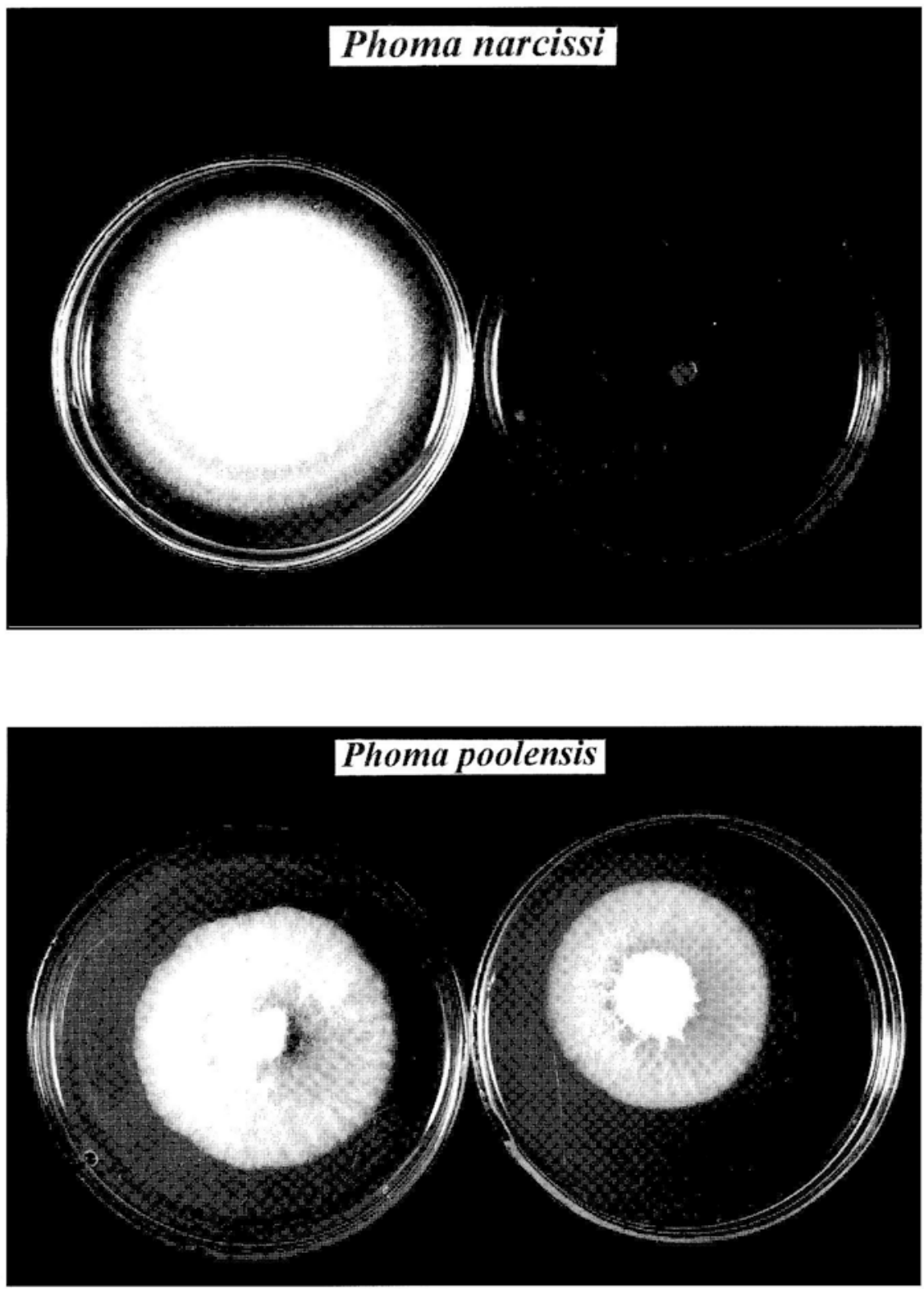

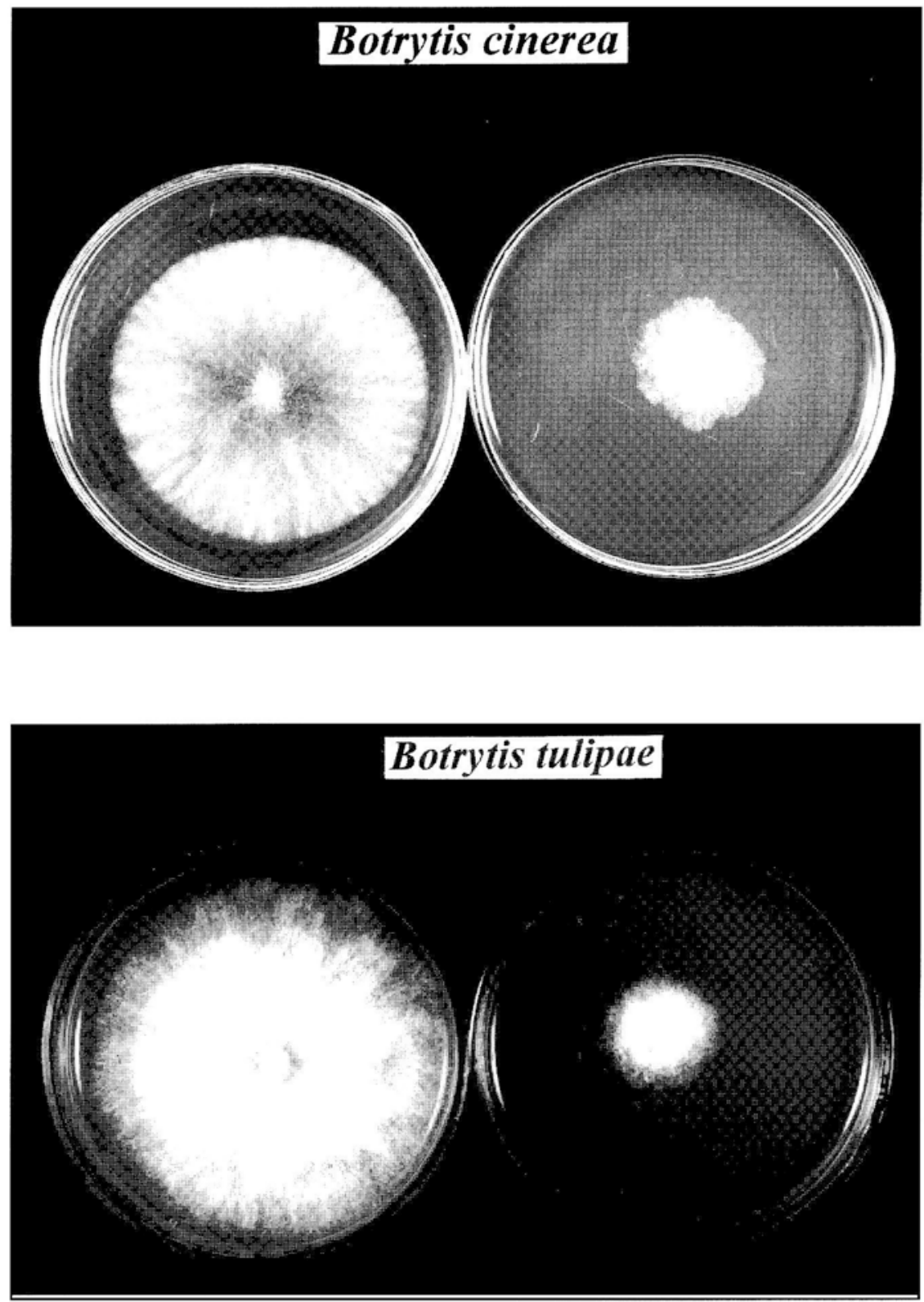

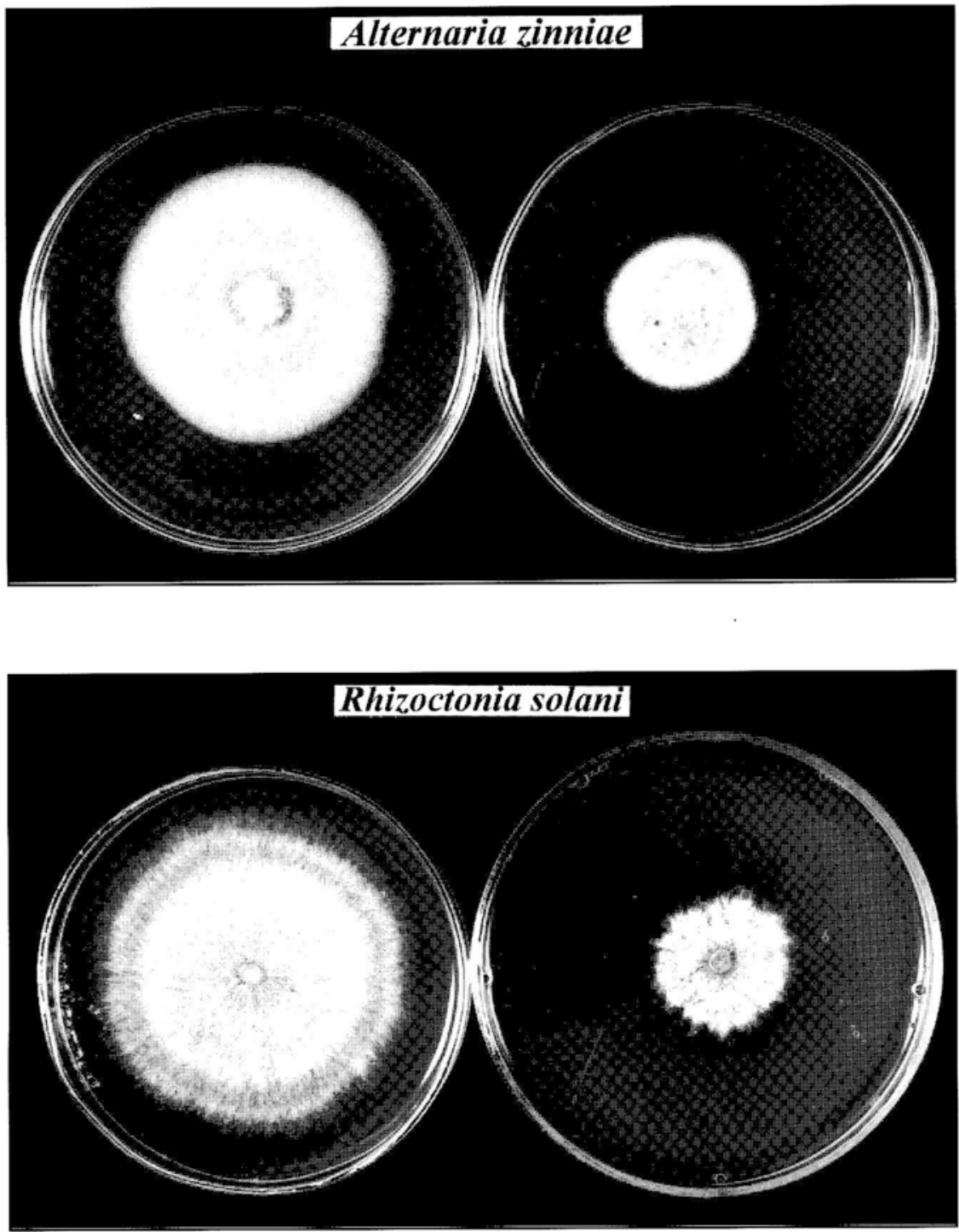